\title{
Biotesting chronic toxicity of waters of surface sources of water service and drinking water on fishes Danio rerio
}

\author{
E. Arystarkhova, \\ candidate of biological sciences, \\ Institute of Agroecology and Environmental Management of National Academie of Agrarian \\ Sciences
}

The purpose. To increase selfdescriptiveness of the method of biotesting waters of surface sources of water service and drinking water due to use of fishes Danio rerio (Brachydanio). Methods. Biotesting with use of the test-reaction of fixation of fishes Poeciliia reticulata Peters and Danio rerio Hamilton-Buchanan with 8-diurnal exposure of individuals. Results. During biotesting at absence of fixation of fishes Poeciliia reticulata Peters toxicity of examined waters is not determined, and on the basis of a fixation of fishes Danio rerio Hamilton-Buchanan the low level of toxicity of waters in the range of $25-50 \%$ is fixed. Conclusions. It is expedient to make assessment of chronic toxicity of waters of surface sources of water service and drinking water by method of biotesting on fishes Danio rerio Hamilton-Buchanan, which have appeared more sensitive to low levels of pollutions (on the average on $26,3 \%$ in acute 4-days experience, and on $36,6 \%$ in chronic 8-days experience), than traditional test-object of fish Poeciliia reticulata Peters.

Key words: biotesting, waters of sources of water service, drinking water, Poeciliia reticulata Peters, Danio rerio Hamilton-Buchanan, fixation, toxicity.

The assessment of water quality in surface water sources and drinking water using physical and chemical analysis does not provide complete information on the complex impact of pollutants on aquatic ecosystems. Therefore, the use of biological methods to determine the toxicity of these waters is particularly relevant [1, 2]. Moreover, the toxicity of drinking water surface waters should be evaluated not only for humans, but also for fish populations and other aquatic organisms [3-8], especially for those who are actively involved in the processes of water quality formation.

Due to the urgent need for monitoring the state of the water from existing methods of biomonitoring, it is expedient to use the biological testing as the obligatory method, which allows, due to high sensitivity, to quickly detect the effects of pollution of surface water sources and drinking water, and at the same time it is much simpler and cheaper in execution, has a time constraint even when determining the chronic toxicity of water and does not require highly qualified labor as physical and chemical methods of research [9-11].

In literary sources during the last decade much attention has been paid to the feasibility of using sets of several highly sensitive organisms related to different levels of biological organization, through which it is possible to assess the state of the aquatic environment [9-13]. Obligatory representatives of such test kits should be vertebrate animals $[10,11]$, including fish. However, not all species of fish behave equally in the same type of water pollution. In addition, some species are able to react more actively to organic compounds, others - on heavy metals, synthetic surfactants or nanomaterials, etc. [2, 12, 13]. To identify the creatures that can provide more accurate information on the level of total water toxicity, a prerequisite is to conduct a comparative analysis of two or more species of fish, the most sensitive of which are the prospect of being used in biotesting of low contaminated waters.

Taking into account the above mentioned features and the existing literature data on the significant increase in the effectiveness of bioassay for the use of highly sensitive organisms [10,11], we consider it necessary to compare two types of unified fish of guppy reticulate (Poecilia reticulata Peters) and danio rerio (Danio rerio Hamilton-Buchanan), which are used in international and national standards for determining the toxicity of water [10-13]. For the first time, for assessing the toxic effects of water using fish, the proposed 
scale of toxicity levels tested on daphnia [4], which is fully consistent with SSanRN (State sanitary rules and norms) 2.2.4-171-10, has been applied.

The goal of the research is to increase the informative value of the method of biotesting water from the surface sources of water supply and drinking water at the expense of the use of danio (Brachydanio) rerio fish.

Materials and methods of research. In order to realize the research objective, a comparative analysis of the biotesting of water toxicity was carried out, a sample of which was selected in prepared dishes from the Denyshivske reservoir and Vidsichne water intake of Teteriv river and from the clean water reservoirs (CWR) of ME "ZhytomyrVodokanal" in April 2016 [4]. After sampling the water was poured into aquariums $\left(10 \mathrm{dm}^{3}\right)$ and formed control and test groups according to the following scheme:

- Control group - a test of a settled (24 hours) tap water;

- Test group D-1: water samples - from Denyshivske reservoir;

- Test group D-2: water samples - from Vidsichne water intake;

- Test group D-3: water samples - with CWR $5000 \mathrm{~m}^{3}$;

- Test group D-4: water samples - with CWR $20000 \mathrm{~m}^{3}$.

Test-objects: female fish of guppy reticulate ( $P$. reticulata) and danio (Brachydanio) rerio (D. rerio) are analogues by age ( 3 weeks) and size $(4,5 \pm 0,5 \mathrm{~cm})$.

Retention: in aquariums, $10 \mathrm{dm}^{3}$ of water, the concentration of oxygen in which is not less than $4 \mathrm{mg} / \mathrm{dm}^{3}$, the temperature $+20^{\circ} \mathrm{C} \pm 2,5^{\circ} \mathrm{C}$, and the density of planting - individual $/ \mathrm{dm}^{3} ;$. in conditions of natural light and replacement of water of appropriate quality every 2 days.

Feeding: from the 5th to the 8th day, dry animal feed (daphnia, ceriodaphnia) twice a day and live plant food (algae, leaves of aquatic plants) constantly.

Test Reaction: Immobilization $\left(I_{M}\right)$, including mortality of individuals.

Exposure: Acute lethal toxicity - for 4 days and short-term chronic toxicity (short-term chronic toxicity) within 8 days.

Biotesting: daily calculation of active and immobilized (including dead) individuals from the 1 st to the 8th day.

Experiments were carried out in 3-time repeat, using standard techniques and own developments [4, 5, $10,12,13]$. The obtained data were compared with the control. For each experimental water sample, the toxicity index (\%) for the SSanRN 2.2.4-171-10 [5] was calculated using the following formula:

$$
T=\frac{I_{k}-I_{0}}{I_{k}} 100,
$$

where: T - index of toxicity, $\%$;

$\mathrm{I}_{\mathrm{k}}$ - the value of the test-reaction of individuals in the control;

$\mathrm{I}_{0}-$ the value of the test-reaction of individuals in the experiment.

The water toxicity index should not exceed $50 \%$ regardless of the test objects used in the studies.

Research results. One of the most important issues in the context of biotesting of water toxicity is the choice of test objects that must be standardized organisms, with which standard experiments have been developed, and which should be adequately responsive to certain levels of pollution of the tested medium. Among the organisms that test biotesting of the aqueous medium is the most commonly used infusoria, daphnia, ceriodaphnia, guppies, common onions, salad dressings, etc. [5-8]. For a long time, these test objects were used to determine the toxicity of natural and sewage, and the development of SSanRN 2.2.4171-10 contributed to their use in water testing of surface water sources and drinking water [5]. However, for biotesting the quality of these waters, which are much cleaner than other species, traditional organisms were not sufficiently informative. In this regard, the search for unified organisms, by means of which higher efficiency compared with generally accepted test objects, can be found low levels of water pollution.

As test organisms, they tested for sensitivity to toxic components of water 2 species of guppy reticulate and danio rerio aquarium fish for the test-reaction of immobilization of individuals, the advantage of which, in 
comparison with many other fish reactions, is the simplicity of its determination for the calculation of the number of active and immobilized individuals. It is known that guppies are the most popular in biotesting as unified vertebrate animal forms. In nature, they are found in tropical waters, which play a large ecological role, removing larvae from mosquitoes and mosquitoes. These are small fish with pronounced sexual dimorphism. The males reach a length of $3-4 \mathrm{~cm}$ and are painted in bright colors (grayish-brown with bright red, blue, green, and black inlays). Females are larger than males $-5-6 \mathrm{~cm}$ in length, with a yellow-green color. Danio is not so often used in biotesting waters as guppy, although it has much better prospects. Under natural conditions, it lives in tropical waters with a slow current of water. The length of the body of adult fish is about $4.5 \mathrm{~cm}$. The body is cylindrical with $7-9$ dark blue horizontal stripes.

Comparative analysis of biotesting with guppy and danio fish of waters from the reservoirs of the Teteriv river and the CWR of Municipal Enterprise "ZhytomyrVodokanal" ( $n=30)$

\begin{tabular}{|c|c|c|c|c|}
\hline \multirow[b]{2}{*}{ Test groups and figures } & \multicolumn{4}{|c|}{ Toxicity after immobilization of test-objects (T, \%): } \\
\hline & guppy reticulate & toxicity level & $\begin{array}{l}\text { danio } \\
\text { rerio }\end{array}$ & toxicity level \\
\hline \multicolumn{5}{|l|}{ Acute toxicity } \\
\hline \multicolumn{5}{|l|}{ D-1 (Denyshivske Reservoir) } \\
\hline & absent & ATL & 31,5 & LTL \\
\hline \multicolumn{5}{|c|}{ D-2 (Vidsichne water intake) } \\
\hline & absent & ATL & 25,8 & ATL \\
\hline $\mathrm{D}-3$ & absent & & & \\
\hline (CWR 5 000) & & ATL & 24,1 & ATL \\
\hline $\mathrm{D}-4$ & absent & & & \\
\hline (CWR 20 000) & & ATL & 23,9 & LTL \\
\hline $\begin{array}{l}\text { Exposure Duration, } \\
\text { days }\end{array}$ & 4 & - & 4 & - \\
\hline \multicolumn{5}{|l|}{ Chronic toxicity } \\
\hline \multicolumn{5}{|c|}{ D-1 (Denyshivske Reservoir) } \\
\hline & absent & ATL & 42,8 & LTL \\
\hline \multicolumn{5}{|l|}{ D-2 (Vidsichne water intake) } \\
\hline & absent & ATL & 38,0 & LTL \\
\hline D-3 & absent & & & \\
\hline (CWR 5 000) & & ATL & 32,5 & LTL \\
\hline D-4 & absent & & & \\
\hline (CWR 20 000) & & ATL & 33,3 & LTL \\
\hline $\begin{array}{l}\text { Exposure Duration, } \\
\text { days }\end{array}$ & 8 & - & 8 & - \\
\hline
\end{tabular}

Note: $I_{M}-$ immobilization of fish;

$\mathrm{T}-$ index of water toxicity (in relation to control);

levels of toxicity of water: ATL - admissible, LTL - low.

A comparative analysis of the environmental effectiveness of biotesting on guppies and danio of water samples taken in the reservoirs of the Teteriv river and the clean water reservoirs (CWR) at the Municipal Enterprise "ZhytomyrVodokanal" is presented in the table.

The obtained data indicate that the test organism proposed for conducting the assessment of the water is danio rerio by the reaction of immobilization of individuals more sensitive to the determination of water toxicity than guppy reticulate. According to the biotesting data, the scale of the water toxicity levels proposed by us is used, which can be used both for the determination of its acute and chronic toxic effects [4]: 1-25\% acceptable level of toxicity; $26-50 \%$ - low toxicity; $51-75 \%$ - average toxicity; $76-100 \%$ - high toxicity. 
In the 90 years of the last century, a standard method for determining the acute lethal toxicity of substances and natural waters was developed on danio rerio [13]. This species of fish should be sensitive enough to the chronic toxic effects of water components of surface water sources and drinking water. Therefore, it is important to compare the sensitivity to the chronic toxicity of water given by danio rerio with such a widespread aquatic toxicology as a species of fish like guppy reticulate.

In the experiment, in the test-reaction of immobilization of guppies, only the permissible level of toxicity was detected in all investigated water species. However, it is obvious that water from surface water sources and drinking water can not have the same toxicity. This fact has been proved by us for the use of a more sensitive species of fish - danio rerio. Thus, for the determination of acute and chronic effects of water, not only the permissible levels of their toxicity (ATL) were revealed, which in fact indicate a lack of harmful effects on organisms, but also low levels (LTL) within the toxicity index of $25-50 \%$. The highest value of the toxicity index was detected in determining the chronic effect of water in the Denyshivske reservoir district of Teteriv, somewhat lower - in the Vidsichne water intake. The determination of the acute effects of water in these groups also revealed higher levels of toxicity compared with the levels of toxicity of drinking water. Although the $50 \%$ limit on water hazard was not exceeded, biotesting with danio rerio was on $26,3 \%$ average (in the acute study) and $36.6 \%$ (in the chronic study) more effective than testing on guppy reticulate.

Consequently, under the same conditions of biotesting with guppy and danio, the latter showed a significantly higher sensitivity to the toxic components of water sources of water supply and drinking water in the conditions of the Municipal Enterprise "ZhytomyrVodokanal".

\section{Conclusions}

The assessment of chronic toxicity of water from surface sources of water supply and drinking water is proposed to be carried out by the method of biotesting with danio rerio fish, which turned out to be more sensitive to low levels of contamination (on average $26,3 \%$ in an acute study of duration 4 days and $36,6 \%$ in the short-term chronic study duration of 8 days) than the traditional test-object of guppy fish.

\section{Bibliography}

1. River watch. Manual for public environmental monitoring. - SPb.: Friends of the Baltics / Coalition Clean Baltics, 2015. -32 p.

2. Nanostructured zinc oxide-cotton fibers: synthesis, characterization and applications / I.M. El-Nahhal, S. M. Zourab, F. S. Kodeh et al. // Jornal of Materials Science: Materials in Electronics. - 2013. - P. 39703975.

3. Malik A. Environmental Deterioration and Human Health: Natural and anthropogenic determinants / A. Malik, E. Grohmann, R. Akhtar. - Dordrecht Heidelberg, London, New York: Springer, 2014. - P. 8-23.

4. Аристархова E.О. Експрес-оцінка потенційної небезпеки води методом біотестування на Daphnia magna S. // Вісник аграрної науки. - 2017. - № 2. - С. 50-54.

5. ДСанПіН 2.2.4-171-10 «Гігієнічні вимоги до води питної, призначеної для споживання людиною» / № 452 / 17747. - МОЗ України. Державні стандартні норми та правила / [чинний від 1.07.2010р.]. - 50 c.

6. Zooplankton (Cladocera) species turnover and long-term decline of Daphnia in two high mountain lakes in the Austrian Alps / L. Nevalainen, M. Ketola, J.B. Korosi et al. // Hydrobiologia. - 2014. - Vol. 722 (1). - P. 75-91.

7. ISO 10706: 2000 Water quality. Determination of long term toxicity of substances to Daphnia magna Straus (Cladocera, Crustacea). -26 p.

8. Jakob U. Oxidative Stress and Redox Regulation / U. Jakob, D. Reichmann. - Dordrecht, Heidelberg, London, New York: Springer, 2013. - P. 59-126.

9. Скок С.В. Оцінювання якості питної води м. Херсона методом біотестування / С.В. Скок // Агроекологічний журнал. - 2015. - № 2. - С.26-30. 
10. Осмалений М.С. Комплексна оцінка токсичності водних зразків за допомогою рослинних і тваринних тест-організмів / М.С. Осмалений, А.М. Головков, А.В. Нанієва, М.Р. Верголяс // Фактори експериментальної еволюції організмів. - 2015. - т.16. - С. 74-77.

11. Пат. 10804 А Україна, МПК G 01 N 33/18; G 01 N 21/76. Спосіб комплексного визначення генетичної безпечності питної води / В.В. Гончарук; заявник та патентовласник В.В. Гончарук; заявл. 5.11.2015, опубл. 11.04.2016, Бюл. № 7.

12. КНД 211.1.4.057-97. Методика визначення гострої летальної токсичності води на рибах Роесіllia reticulata Peters.

13. ISO 7346-1:1996 Water quality. Determination of the acute lethal toxicity of substances to a freshwater fish [Brachydanio rerio Hamilton-Buchanan (Teleostei, Cyprinidae)]. - Part 1: Static method. 